\title{
Intraruminal administration of two doses of quebracho tannins to sheep: effect on rumen degradation and total tract digestibility, faecal recovery and toxicity ${ }^{*}$
}

\author{
G. Hervás ${ }^{1}$, P. Frutos, G. Ramos, F.J. Giráldez and A.R. Mantecón \\ Estación Agrícola Experimental, Spanish Council for Scientific Research (CSIC) \\ Apdo. 788, 24080-León, Spain
}

(Received 21 March 2003; revised version 16 September 2003; accepted 14 January 2004)

\begin{abstract}
Nine rumen fistulated ewes fed lucerne hay were intra-ruminally dosed for a period of 51 days with $0\left(\mathrm{Q}_{0}\right), 35\left(\mathrm{Q}_{1}\right)$ and $70\left(\mathrm{Q}_{2}\right) \mathrm{g}$ of quebracho condensed tannin $(\mathrm{CT})$ extract $/ \mathrm{kg}$ feed daily. Lucerne hay in situ DM, N and NDF 24 h disappearance were significantly lower $(\mathrm{P}<0.05)$ in those sheep dosed with the highest level of quebracho extract $\left(\mathrm{Q}_{2}\right)$ compared with the other two groups $\left(\mathrm{Q}_{0}\right.$ and $\mathrm{Q}_{1}$ ). The rumen ammonia-N concentration was also lower in groups treated with quebracho. Neither of the doses affected in vivo DM, NDF or ADF digestibility. However, both reduced apparent CP digestibility $(\mathrm{P}<0.01)$. Faecal analyses showed a $30 \%$ recovery of the administered $\mathrm{CT}$, regardless of the dose $(\mathrm{P}>0.10)$. There were no signs of intoxication by tannins in any of the treatments.
\end{abstract}

KEY WORDS: condensed tannins, digestibility, quebracho, rumen degradation, sheep

\section{INTRODUCTION}

Condensed tannins (CT), or proanthocyanidins, are widespread in woody plants, but are also found in a number of forages. Their capability to form complexes with proteins and other macromolecules has important nutritional and physiological consequences.

\footnotetext{
* Supported by the Inter-Ministerial Commission of Science and Technology (CICYT) of Spain, Project AGF98-0874

${ }^{1}$ Corresponding author: e-mail: hervas@eae.csic.es
} 
CT have long been recognised as antinutritional factors that can depress voluntary feed intake and reduce ruminal fibre degradation and digestibility of feedstuffs. Recent studies, however, point to the importance of considering their dosage-dependent effect and suggest that low to moderate concentrations may prevent bloat in grazing animals and produce significant increases in wool growth, liveweight gain, and milk production. These beneficial effects appear to be associated with the formation of tannin-protein complexes that protect dietary protein from degradation in the rumen and subsequently enhance amino acid absorption and utilization by the ruminant (Aerts et al., 1999).

CT effects are highly dependent on the type of tannin since condensed tannins comprise a highly complex group of polyphenolic compounds. Commercial quebracho tannin extract (obtained from Schinopsis spp.; 76\% CT) has been found to protect soyabean meal protein from rumen degradation in sheep without detrimentally affecting its intestinal digestion (Frutos et al., 2000), and to have antihelmintic properties when consumed by parasited sheep (Athanasiadou et al., 2000). A positive effect in bloat prevention would also be expected (McMahon et al., 2000). However, before suggesting their use as a potential feed additive, further studies on their in vivo effects was considered advisable.

The present work was conducted to study the effect of administering two different levels of quebracho CT extract to sheep for a period of 51 days on rumen fermentation activity and diet digestibility. In addition, CT recovery in faeces was determined and a histopathological study conducted.

\section{MATERIAL AND METHODS}

\section{Animals and diet}

Nine individually penned Merino ewes (mean BW $52.6 \mathrm{~kg}$, s.e. 3.01), fitted with ruminal cannulae, were assigned to one of three treatment groups $\left(\mathrm{Q}_{0}, \mathrm{Q}_{1}\right.$ and $\mathrm{Q}_{2}$ ) of three animals each, balanced for BW. They were offered dehydrated lucerne hay $(926 \mathrm{~g}$ dry matter $(\mathrm{DM}) / \mathrm{kg} ; 151 \mathrm{~g}$ crude protein $(\mathrm{CP}) / \mathrm{kg} \mathrm{DM} ; 438 \mathrm{~g}$ neutral-detergent fibre (NDF)/kg DM; $334 \mathrm{~g}$ acid-detergent fibre (ADF)/kg DM) in two equal meals (at 09.30 and $18.00 \mathrm{~h}$ ) at 1.2 times their estimated maintenance requirements (AFRC, 1993). Water and vitamin-mineral blocks were freely available. The animals were cared for in accordance with the guidelines and ethical considerations established by the Spanish Council for Scientific Research (CSIC).

\section{Experimental treatments}

Quebracho tannin extract (containing 760 g CT/kg; Roy Wilson Dickson Ltd., UK) was dissolved in $300 \mathrm{ml}$ of distilled water containing $0.08 \mathrm{ml}$ of methanol/1, 
and dosed into the rumen of the ewes in three doses of approx. $100 \mathrm{ml}$ at about 5 min intervals, using a syringe and a flexible tube to distribute the quebracho extract solution in the rumen.

The dose rates of quebracho $\mathrm{CT}$ extract were $0.0 \mathrm{~g} / \mathrm{kg}$ feed $\left(\mathrm{Q}_{0}\right.$, placebo), 35 $\mathrm{g} / \mathrm{kg}$ feed $\left(\mathrm{Q}_{1}\right)$ and $70 \mathrm{~g} / \mathrm{kg}$ feed $\left(\mathrm{Q}_{2}\right)$. Ewes received the solution once daily, immediately before the morning feeding, for a period of 51 days.

\section{In situ rumen incubations}

On days $0,3,7,14,21,28$ and 42 of the experiment, lucerne hay DM, nitrogen $(\mathrm{N})$ and NDF disappearance were determined using the nylon bag $(45 \mu \mathrm{m}, 165 \times$ $105 \mathrm{~mm}$; Maissa ${ }^{\circledR}$, Spain) technique (Mehrez and Ørskov, 1977).

Lucerne samples (4 g), milled to pass a 2-mm screen, were incubated in duplicate in the rumen of each of the ewes for $24 \mathrm{~h}$. The bags were introduced immediately after quebracho administration and before the morning feeding. After removal from the rumen, the bags were washed with cold tap water, and frozen $\left(-30^{\circ} \mathrm{C}\right)$ for $24 \mathrm{~h}$ to help remove microbial attachment to feed particles. Once defrosted, bags were washed again with cold water in a commercial washing machine, dried in a forced-air oven at about $40-50^{\circ} \mathrm{C}$ and weighed to determine DM losses. $\mathrm{N}$ and NDF concentration in the residues were measured to determine $\mathrm{N}$ and NDF disappearance (ND and NDFD, respectively).

\section{Ammonia- $N$}

On days 3, 7, 14 and 21 of the experiment, rumen fluid samples were obtained from each sheep immediately before quebracho dosing and morning feeding (at $9.00 \mathrm{~h})$. Strained rumen fluid $(10 \mathrm{ml})$ was acidified $(1: 1 \mathrm{v} / \mathrm{v})$ with $0.2 \mathrm{~N} \mathrm{HCl}$ for ammonia-N determination. Samples were stored at $-30^{\circ} \mathrm{C}$ until analysis.

\section{In vivo digestibility and CT recovery in faeces}

On the last week of the experiment (from day 43 to day 50), the animals were housed in standard metabolic cages to study the in vivo digestibility of the diet. The trial consisted of a preliminary 3-day adaptation period, followed by a 5-day measurement period of total faecal collection. Faeces of each animal were collected daily, weighed, thoroughly mixed and sampled (10\%). Aliquots for each sheep were bulked, and the pooled sample dried, weighed, ground and stored for chemical analysis of N, NDF and ADF. The CT content in faeces was also analysed.

\section{Histopathological study}

At the end of the experiment (after 51 days of quebracho administration), two ewes from treatment $\mathrm{Q}_{1}$ and two from $\mathrm{Q}_{2}$ were euthanased by intravenous injec- 
tion of barbiturate (Euta-lender ${ }^{\circledR}$, Normón, Spain) and complete post-mortem examination was performed. Samples for histopathological examination were collected from the liver, kidneys, heart, lungs, pancreas, spleen, mesenteric and mediastinal lymph nodes, and several segments of the digestive tract (oesophagus, reticulum, rumen, omasum, abomasum, small intestine (duodenum, jejunum and ileum), caecum, colon and rectum). Tissues were fixed in $10 \%$ neutral buffered formalin and stained with haematoxylin-eosin.

Gross and histopathological examination was focused on the presence of lesions associated with tannin toxicosis, characterized by congestion, erosions and necrosis in the digestive tract mucosa together with liver and renal tubular cell degenerative changes.

\section{Chemical analysis}

Samples of the diet, incubation residues and faeces were milled to pass a 1 $\mathrm{mm}$ screen. Procedures described by AOAC (1999) were used to determine DM, ash and Kjeldahl N. NDF and ADF were determined by the method of Goering and Van Soest (1970), using an Ankom ${ }^{200 \otimes}$ analyser with the addition of sodium sulphite. Rumen ammonia-N concentrations were determined, in duplicate, as described by Weatherburn (1967), in centrifuged samples.

CT fractions (free, protein-bound and fibre-bound) were sequentially extracted from the faeces, in duplicate, according to Perez-Maldonado and Norton (1996b), to determine total condensed tannin content. Analyses were conducted, in triplicate, by the butanol-HCl method (Terrill et al., 1992), using purified quebracho CT as the reference standard. The purification was performed with Sephadex LH20 as described by Hagerman and Butler (1994).

\section{Statistical analysis}

Analysis of in situ DM, N and NDF disappearances and ammonia-N concentration were conducted by repeated measurements, using the MIXED procedure of the SAS (1989) package. Data on digestibility coefficients and CT recovery were subjected to one-way analysis of variance to examine the effect of quebracho treatments using the MIXED procedure (SAS, 1989).

\section{RESULTS}

Mean in situ DM, N and NDF disappearances (DMD, ND and NDFD, respectively; Table 1$)$ were significantly lower $(\mathrm{P}<0.05)$ in sheep dosed with the highest level of quebracho $\left(Q_{2}\right)$. No differences were observed between groups $Q_{0}$ and $Q_{1}$. 


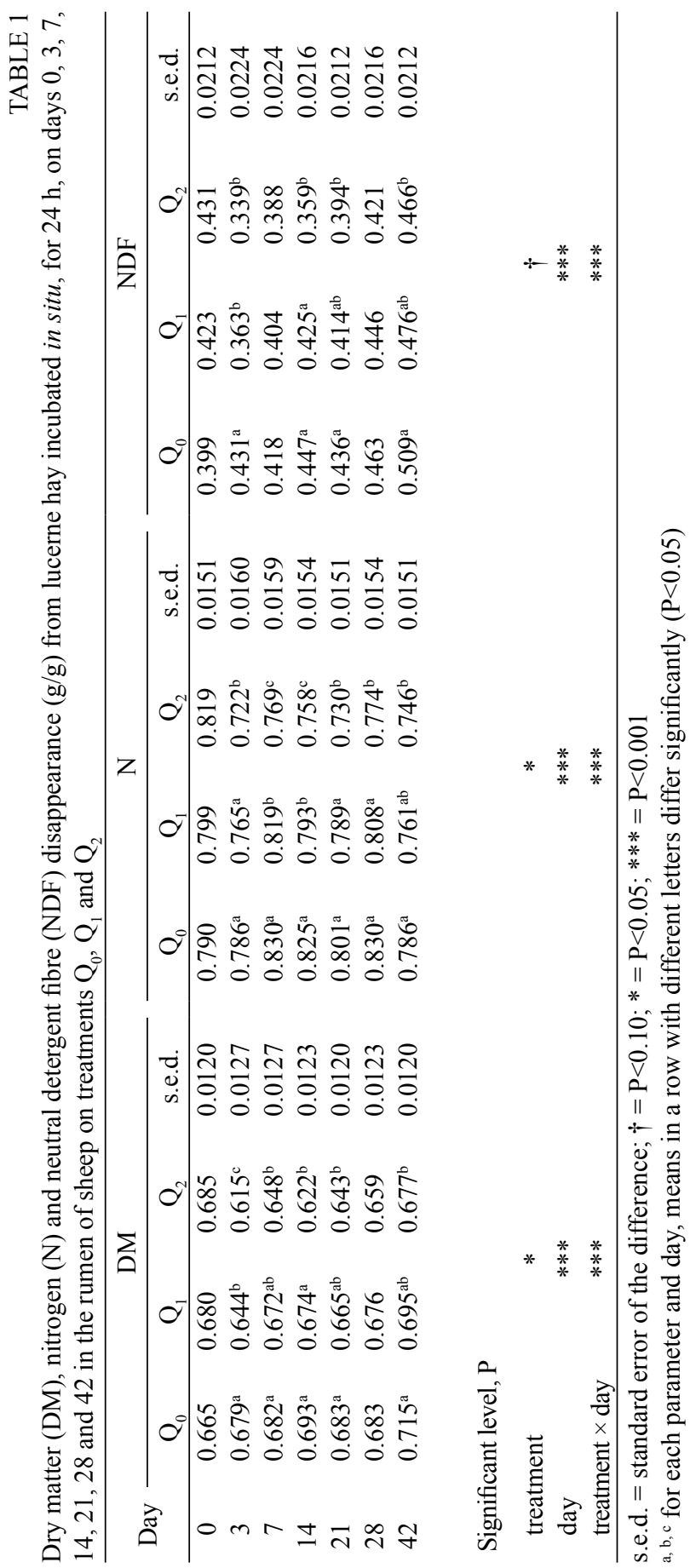


After three days, the $\mathrm{Q}_{1}$ dose significantly $(\mathrm{P}<0.05)$ reduced DM and NDF disappearance but had no effect on $\mathrm{N}$ disappearance. This effect was variable, as at both 7 and 14 days of administration, $\mathrm{Q}_{1}$ reduced ND $(\mathrm{P}<0.05)$ but had no significant effect on DMD or NDFD. Later on in the study, only $Q_{2}$ values were significantly different $(\mathrm{P}<0.05)$ from those of controls $\left(\mathrm{Q}_{0}\right)$. Interaction "treatment $\times$ day" was statistically significant $(\mathrm{P}<0.001)$ for the three components ( $\mathrm{DM}, \mathrm{N}$ and $\mathrm{NDF}$ ).

Quebracho treatments significantly reduced $(\mathrm{P}<0.01)$ the ruminal ammonia-N concentration, this effect being directly related to level of quebracho delivered (mean values were 343, 268 and $184 \mathrm{mg} / 1$ for $\mathrm{Q}_{0}, \mathrm{Q}_{1}$ and $\mathrm{Q}_{2}$, respectively). No significant "treatment $\times$ day" interaction $(\mathrm{P}>0.10)$ was observed. Neither of the quebracho treatments affected DM, NDF or ADF digestibility ( $\mathrm{P}>0.10$; Table 2). However, both of them reduced $\mathrm{N}$ apparent digestibility $(\mathrm{P}<0.01)$.

TABLE 2

DM, N, NDF and ADF digestibility of the lucerne hay in ewes on treatments $\mathrm{Q}_{0}, \mathrm{Q}_{1}$ and $\mathrm{Q}_{2}$

\begin{tabular}{lccccc}
\hline Nutrients & \multicolumn{3}{c}{ Treatment } & s.e.d. & $\begin{array}{c}\text { Significant } \\
\text { level, } \mathrm{P}\end{array}$ \\
\cline { 2 - 4 } & $\mathrm{Q}_{0}$ & $\mathrm{Q}_{1}$ & $\mathrm{Q}_{2}$ & & NS \\
$\mathrm{DM}$ & 0.590 & 0.538 & 0.551 & 0.0334 & $* *$ \\
$\mathrm{~N}$ & $0.739^{\mathrm{a}}$ & $0.672^{\mathrm{b}}$ & $0.674^{\mathrm{b}}$ & 0.0154 & $\mathrm{NS}$ \\
$\mathrm{NDF}$ & 0.496 & 0.463 & 0.484 & 0.0542 & $\mathrm{NS}$ \\
\hline
\end{tabular}

s.e.d. $=$ standard error of the difference; $\mathrm{NS}=\mathrm{P}>0.10 ; * *=\mathrm{P}<0.01$

${ }^{\mathrm{a}, \mathrm{b}}$ for each parameter, means in a row with different letters differ significantly $(\mathrm{P}<0.05)$

Results of the analyses of CT in the faeces of animals dosed with quebracho extract showed a recovery of $30 \%$ of the amount of CT administered into the rumen (17.59 vs $35.94 \mathrm{~g} \mathrm{CT} / \mathrm{kg}$ DM faeces), regardless of the dose ( $\mathrm{P}>0.10)$.

All sheep remained healthy throughout the experimental period and consumed the entire ration offered. There were no signs of intoxication by quebracho extract either at necropsy or following histological examination (neither erosions nor ulcers were seen in the gastric and intestinal mucosa, and the liver and kidney did not present any sign of parenchymal degeneration).

\section{DISCUSSION}

Condensed tannins have been widely reported to be able to decrease rumen degradation of feeds. This effect probably results from a reduction in the attachment of microbes to feed particles (McAllister et al., 1994) and inhibition of microbial growth and enzymatic activity (Waghorn, 1996; McSweeney et al., 2001). However, a number of rumen microorganisms have been found to tolerate relatively high concentrations of condensed tannins; this effect being dose-dependent. In this 
respect, Bae et al. (1993) observed that the net effect of exposure of Fibrobacter succinogenes S85, a predominantly cellulolytic rumen bacterial species, to condensed tannins ( 0 to $300 \mu \mathrm{g} / \mathrm{ml})$ was a transient increase in the activity of cell-associated endoglucanases that compensated the decline in the activity of extracellular endoglucanases. As the concentrations of CT approached $400 \mu \mathrm{g} / \mathrm{ml}$, all endoglucanases were inhibited and cellulose degradation ceased. Similarly, O'Donovan and Brooker (2001) reported that some proteolytic rumen bacteria were able to modify their metabolism and thus provide the organisms with a selective advantage over other strains when grown in the presence of phenolic compounds. These bacteria were, therefore, initially sensitive to tannins and this may, to some extent, explain the reduction in rumen degradation measured during the first two weeks of quebracho administration. The subsequent lack of treatment effect differences between $\mathrm{Q}_{1}$ and $\mathrm{Q}_{0}$ later in the experiment suggests that the $\mathrm{Q}_{1}$ dose was insufficient to adversely affect the majority of the rumen microbial population.

The reduction in proteolysis as a consequence of the effect of CT, and the subsequent lowered concentration of ammonia- $\mathrm{N}$ in the rumen fluid has been identified by many authors (Waghorn, 1996). In agreement with those findings, data concerning ammonia-N concentration in this experiment were in parallel with those of ND.

In vivo digestibility. Condensed tannins have been shown to significantly reduce the apparent digestibility of dietary protein and increase faecal $\mathrm{N}$ excretion (Waghorn, 1996). CT can not only protect dietary protein against rumen degradation, but also induce a depressive effect on digestive tract enzyme activities (Silanikove et al., 1994). However, the greater faecal N excretion is most likely a consequence of a higher secretion of endogenous proteins (salivary proteins, digestive enzymes, mucus or mucosal cells). In this experiment, the $\mathrm{Q}_{1}$ treatment appears sufficient to reduce the apparent digestibility of CP. This is in agreement with the small amount of CT required to decrease this parameter (Waghorn and Shelton, 1997). On the other hand, no effect of the treatment was observed on NDF and ADF digestibilities, although CT are known to be able to reduce fibre digestion (McSweeney et al., 2001).

Recovery of CT in faeces. There is large variation in the published CT faecal recovery values in sheep. Values are usually low: 15, 22 or 32\% (from Terrill et al., 1994 and Perez-Maldonado and Norton, 1996a,b, respectively) but some as high as $77 \%$ (Robbins et al., 1991). According to several studies (e.g., Terrill et al., 1994; McSweeney et al., 2001), it seems improbable that the low recovery of $\mathrm{CT}$ in the faeces is due to CT metabolism during passage through the gastrointestinal tract. Although Perez-Maldonado and Norton (1996a) stated that CT from Desmodium intortum were digested and/or absorbed in the digestive tract, many other authors point out that there is no evidence of cleavage of the heterocyclic ring system of flavan-3-ols, that are the monomeric units of CT. Depolymerization of CT by cleavage of carbon-carbon bonds has not been demonstrated under 
anaerobic conditions and is unlikely to occur in the rumen (Terrill et al., 1994; McSweeney et al., 2001).

Low CT recoveries are considered to be a consequence of either structural changes to the CT molecule such that it is no longer detectable by colorimetric methods, an inability of the analytical method to release bound CT with the butanol-HCl assay, or interference from other digesta constituents, such as pigments (Robbins et al., 1991; Terrill et al., 1994; Perez-Maldonado and Norton, 1996a,b).

Histopathological study. Neither gross lesions nor microscopic changes were observed in any of the tissues examined. Had indications of toxicity been found, all animals would have been euthanased to obtain additional data. However, due to the lack of evidence additional slaughters were not considered. The lack of lesions was consistent with the study of Hervás et al. (2003), in which it was observed that the quebracho tannin extract was not toxic to sheep, except in concentrations too high to be encountered under practical conditions. In that study no sign of toxicity was found when ewes received approx. $83 \mathrm{~g} / \mathrm{kg}$ DM feed.

Quebracho CTs are profisetinidins with more compact, less accessible structures than other CTs such as procyanidins or prodelphinidins (Mueller-Harvey and McAllan, 1992), which may mean less biological reactivity. Thus, even though quebracho (Schinopsis spp.) CT extract has been widely used in many studies of ruminant nutrition, its use as a "model tannin" to predict other tannin activities is very inadvisable and specific results obtained with these particular CTs cannot be directly extrapolated to other CTs.

\section{ACKNOWLEDGEMENTS}

The authors wish to thank Dr. V. Pérez from the University of León (Spain) for conducting the histopathological study and Dr. F.L. Mould from the University of Reading (UK) for helpful comments and revision of the manuscript.

\section{REFERENCES}

Aerts R.J., Barry T.N., McNabb W.C., 1999. Polyphenols and agriculture: beneficial effects of proanthocyanidins in forages. Agr. Ecosyst. Environ. 75, 1-12

AFRC, 1993. Energy and Protein Requirements of Ruminants. An Advisory Manual Prepared by the AFRC Technical Committee on Responses to Nutrients. CAB International, Wallingford (UK) AOAC, 1999. Official Methods of Analysis, Association of Official Agricultural Chemists. $16^{\text {th }}$ Edition. Gaithersburg, MD

Athanasiadou S., Kyriazakis I., Jackson F., Coop R.L., 2000. Consequences of long-term feeding with condensed tannins on sheep parasited with Trichostrongylus colubriformis. Int. J. Parasitol. $99,1025-1033$ 
Bae H.D., McAllister T.A., Yanke L.J., Cheng K.-J., Muir A.D., 1993. Effects of condensed tannins on endoglucanase activity and filter paper digestion by Fibrobacter succinogenes S85. Appl. Environ. Microbiol. 59, 2132-2138

Frutos P., Hervás G., Giráldez F.J., Fernández M., Mantecón A.R., 2000. Digestive utilization of quebracho-treated soya bean meals in sheep. J. Agr. Sci. 134, 101-108

Goering M.K., Van Soest P.J., 1970. Forage Fiber Analysis (Apparatus, Reagents, Procedures and Some Applications). Agriculture Handbook, No. 379. Agricultural Research Service, USDA. Washington

Hagerman A.E., Butler L.G., 1994. Assay of condensed tannins or flavonoid oligomers and related flavonoids in plants. Meth. Enzymol. 234, 429-437

Hervás G., Pérez V., Giráldez F.J., Mantecón A.R., Almar M.M., Frutos P., 2003. Intoxication of sheep with quebracho tannin extract. J. Comp. Pathol. 129, 44-54

McAllister T.A., Bae H.D., Jones G.A., Cheng K.-J., 1994. Microbial attachment and feed digestion in the rumen. J. Anim. Sci. 72, 3004-3018

McMahon L.R., McAllister T.A., Berg B.P., Majak W., Acharya S.N., Popp J.D., Coulman B.E., Wang Y., Cheng K.-J., 2000. A review of the effects of forage condensed tannins on ruminal fermentation and bloat in grazing cattle. Can. J. Plant Sci. 80, 469-485

McSweeney C.S., Palmer B., McNeill D.M., Krause D.O., 2001. Microbial interactions with tannins: nutritional consequences for ruminants. Anim. Feed Sci. Tech. 91, 83-93

Mehrez A.Z., Ørskov E.R., 1977. A study of the artificial fibre bag technique for determining the digestibility of feeds in the rumen. J. Agr. Sci. 88, 645-650

Mueller-Harvey I., McAllan A.B., 1992. Tannins: Their biochemistry and nutritional properties. In: I.M. Morrison (Editor). Advances in Plant Cell Biochemistry and Biotechnology. Vol. 1. JAI Press Ltd., London, pp. 151-217

O'Donovan L., Brooker J.D., 2001. Effect of hydrolysable and condensed tannins on growth, morphology and metabolism of Streptococcus gallolyticus (S. caprinus) and Streptococcus bovis. Microbiology 147, 1025-1033

Perez-Maldonado R.A., Norton B.W., 1996a. Digestion of ${ }^{14} \mathrm{C}$-labelled condensed tannins from $\mathrm{De}$ smodium intortum in sheep and goats. Brit. J. Nutr. 76, 501-513

Perez-Maldonado R.A., Norton B.W., 1996b. The effects of condensed tannins from Desmodium intortum and Calliandra calothyrsus on protein and carbohydrate digestion in sheep and goats. Brit. J. Nutr. 76, 515-533

Robbins C.T., Hagerman A.E., Austin P.J., McArthur C., Hanley T.A., 1991. Variation in mammalian physiological responses to a condensed tannin and its ecological implications. J. Mammal. $72,480-486$

SAS, 1989. SAS/STAT ${ }^{\circledR}$. User's Guide Int. $4^{\text {th }}$ Edition. SAS Institute Inc. Cary, NC (USA)

Silanikove N., Nitsan Z., Perevolotsky A., 1994. Effect of a daily supplementation of polyethylene glycol on intake and digestion of tannin-containing leaves (Ceratonia siliqua) by sheep. J. Agr. Food Chem. 42, 2844-2847

Terrill T.H., Rowan A.M., Douglas G.B., Barry T.N., 1992. Determination of extractable and bound condensed tannin concentrations in forage plants, protein concentrate meals and cereal grains. J. Sci. Food Agr. 58, 321-329

Terrill T.H., Waghorn G.C., Woolley D.J., McNabb W.C., Barry T.N., 1994. Assay and digestion of ${ }^{14} \mathrm{C}$-labelled condensed tannins in the gastrointestinal tract of sheep. Brit. J. Nutr. 72, 467-477

Waghorn G., 1996. Condensed tannins and nutrient absorption from the small intestine. In: L.M. Rode (Editor). Proceedings of the 1996 Canadian Society of Animal Science. Annual Meeting. Lethbridge (Canada), pp. 175-194

Waghorn G.C., Shelton I.D., 1997. Effect of condensed tannins in Lotus corniculatus on the nutritive value of pasture for sheep. J. Agr. Sci. 128, 365-372

Weatherburn M.W., 1967. Phenol-hypochlorite reaction for determination of ammonia. Anal. Chem. $39,971-974$ 


\section{STRESZCZENIE}

Wpływ dożwaczowego podawania owcom tanin drzewa quebracho na degradację składników pokarmowych w żwaczu, pozorną strawność, wydalanie tanin w kale oraz ich toksyczność

Dziewięciu owcom - maciorkom, z przetokami do żwacza, żywionymi sianem z lucerny, podawano przez 51 dni skondensowany ekstrakt taniny z drzewa quebracho $(\mathrm{CT})$ w ilości $0\left(\mathrm{Q}_{0}\right), 35\left(\mathrm{Q}_{1}\right)$ lub 70 $\left(Q_{2}\right) \mathrm{g} / \mathrm{kg}$ paszy/dzień. Trawienie in situ s.m., N i NDF siana z lucerny w ciągu 24 godz. było istotnie mniejsze $(\mathrm{P}<0,05)$ u owiec otrzymujących największą dawkę $\mathrm{Q}_{2}$ w porównaniu z pozostałymi grupami. Stężenie $\mathrm{N}_{-} \mathrm{NH}_{3}$ w żwaczu było także niższe u zwierząt otrzymujących quebracho. Strawność s.m., NDF i ADF nie zależała od dodatku tanin, natomiast obniżona $(\mathrm{P}<0,01)$ została strawność białka ogólnego przy obydwóch dawkach tanin. W kale odzyskano $30 \%$ podanych tanin, niezależnie od ilości podanej $(\mathrm{P}>0,10)$. Nie stwierdzono żadnych objawów zatrucia spowodowanego dodatkiem tanin. 